\title{
Effective treatment of resistant Escherichia coli infection, with sulphadimidine stabilized in a synthetic Aluminium-Magnesium Silicate
} \author{
Idika I. Kalu ${ }^{2}$, Mfon E. Esen ${ }^{1}$ \\ ${ }^{1}$ Department of Veterinary Medicine, University of Nigeria, Nsukka, Nigeria; \\ *Corresponding Author: maduikeezeibe@yahoo.com \\ ${ }^{2}$ Department of Veterinary Parasitology and Entomology, University of Nigeria, Nsukka, Nigeria
}

Maduike C. O. Ezeibe ${ }^{1 *}$, Uchenna M. Chima ${ }^{1}$, Augustine A. Ngene $^{1}$, Obianuju N. Okoroafor ${ }^{1}$,

Received 23 September 2012; revised 23 October 2012; accepted 5 November 2012

\begin{abstract}
To investigate if Aluminium-Magnesium Silicate (AMS) could make drugs regain effects against resistant pathogens, its effect was tested on sulphadimidine against sulphadimidine-resistant Escherichia coli. Two groups of chicks infected with sulphadimidine-resistant $E$. coli were treated at sulphadimidine dose rate of $1 \mathrm{~g} /$ litre of drinking water, with sulphadimidine and with an AMS-sulphadimidine drug formulation, respectively. Two other groups were similarly treated at sulphadimidine dose rate of 0.75 g/litre, while the fifth group served as control. Mean titres of the bacterium in bile of the chicks were compared. Titres, $119,200 \pm 55,800 \mathrm{CFU} / \mathrm{mL}$ of the group treated with sulphadimidine at rate of $1 \mathrm{~g} /$ litre and $14,800 \pm 1700 \mathrm{CFU} / \mathrm{mL}$ of the group treated at rate of $0.75 \mathrm{~g} /$ litre, did not vary from $33,200 \pm 5200 \mathrm{CFU} / \mathrm{mL}$ of the control $(P>0.05)$ but $295,200 \pm 106,400 \mathrm{CFU} / \mathrm{ml}$ of the group treated at rate of $1 \mathrm{~g} / \mathrm{litre}$, with the AMS-sulphadimidine drug was significantly $(P<0.05)$ higher than that of the control while $5200 \pm 1400$ CFU $/ \mathrm{mL}$ of the group treated at dose of $0.75 \mathrm{~g} / \mathrm{li}-$ tre, with the AMS-sulphadimidine drug, reduced significantly $(P<0.05)$.
\end{abstract}

Keywords: Resistant Pathogens; Escherichia coli; Sulphadimidine; Aluminium-Magnesium Silicate; Nanoparticles

\section{INTRODUCTION}

Development of resistance against drugs by disease causing microrganisms has become a major concern both in veterinary medicine and in humanbeings [1]. Bacteria are among the pattogens that often develope resistance against drugs and among bacteria, Escherichia coli is often involved in drug resistance [2].

Most cases of $E$. coli infections of humanbeings are contracted from foods of animal origin [3,4]. Though $E$. coli is part of normal flora of gastrointestinal tract of animals and humanbeings [3], under adverse conditions, some strains become pathogenic [4,5]. Ewers et al. [2] had reported that over $80 \%$ cases of cystitis in humanbeings are due to $E$. coli.

In poultry, infection by pathogenic $E$. coli is of great significance, world wide. It is responsible for a number of conditions in poultry [6]. The most common conditions associated with avian collibacillosis include, septicemia, peritonitis and salpingitis in breeders. In comercial broilers, collibacillosis is often associated with airsacculitis, septicemia and cellulitis [7]. Because collibacillosis is a zoonosis, avian collibacillosis is of economic importance, because, it leads to condemnation of chicken at meat inspection.This is in addition to increased mortality and decreased performance of poultry [8].

The practice of adding antimicrobials in feeds of animals, as growth promoters, leads to development of resistance by avian E. coli. These drug resistant infections often find their way into the human food chain [9], thus increasing public health importance of avian collibacillosis.

Sulphadimidine and the other sulphonamides were the first chemotherapeutic agents employed for systemic treatment and for prevention of bacterial infections in humans and animals [10]. Sulphonamides have wide range of antimicrobial activity against gram-positive bacteria, gram-negative bacteria and protozoans. However, strains of bacteria resistant to the sulphonamides have become common, thus diminishing usefulness of this class of antibacterial agents [11].

Each molecule of Aluminium-Magnesium Silicate (AMS) is composed of submicroscopic platelets, $1 \mathrm{~nm}$ thick [12]. So, AMS is made of nanoparticles [13]. Faces 
of the platelets possess negative electrical charges, while the edges have the positive charges [12]. So, when in solution, AMS hydrates to form three dimentional colloidal structures which stabilize any drug AMS is in combination with [14]. For this reason, it has been in use as stabilizing agent for drugs used in treatment of animals and humanbeings for many decades [15]. To stabilize drugs means to make the drugs retain their chemical nature [16]. Also, it has been reported that AMS is a zeolite and that zeolites have ability to absorb water and drugs without change in their crystal structures. This leads to prolonged bioavailability of the drugs [17].

When high concentrations of drugs remain in blood of treated animals for a long time or when bioavailability of drugs is prolonged, their actions improve [18].

A synthetic AMS has been used to improve ability of Chloroquine phosphate to reduce Plasmodium berghei parsitaemia [19], ability of Ampicillin trihydrate to improve clearance of Salmonella gallinarium [20], ability of sulphadimidine to reduce coccidia oocysts per gramme of faeces of infected chicks [21] and ability of piperazine citrate to reduce eggs of Helignosomoides bakeri in faeces of infected mice [22].

It was therefore, thought usefull to use the synthetic AMS to retain high concentration of sulphadimidine in blood of treated chicks. This may make sulphadimidine regain its antibacterial effect against the resistant $E$. coli.

When AMS was used to stabilize Ampicillin trihydrate to test its effect on ability of the antibiotic to inhibit Salmonrlla gallinarum, it had no significant effect on the bacterium in the in vitro studies. But in vivo, it was able to increase ability of Ampicillin to clear S. gallinarium infection from $81 \%$ to $98 \%$ [20]. It was concluded that AMS improves actions of drugs in vivo but has no effect in vitro [20]. This improved effects of drugs is a result of ability of the AMS to reduce rate of metabolic degradation of the drugs in blood of treated animals which prolongs bioavailability of the drug $[17,18]$. AMS does not increase potency of drugs in vitro [20]. Any test of ability of AMS to improve actions of drugs against resistant pathogens should therefore be by in vivo studies with live animals [20].

\section{MATERIALS AND METHODS}

Twentyfive cockerel chicks were infected with a sulphadimidine-resistant E. coli isolate. Each chick was given (per os) $0.1 \mathrm{~mL}$ of a sample of the bacterium that had bacterial titre of 15,000,000/mL [5].

Six days post infection, the chicks were randomly divided into five groups.Two groups were treated at sulphadimidine dose rate of $1 \mathrm{~g} /$ litre with a $100 \%$ sulphadimidine powder and with a drug formulation of $20 \%$ sul phadimidine in AMS, respectively. Two other groups were also treated with the $100 \%$ sulphadimidine and with the AMS-sulphadimidine drug formulation at sulphadi- midne dose rate of $0.75 \mathrm{~g} /$ litre. The fifth group served as untreated control.

After 5 days of treatment, the chicks were sacrificed. Muscles and organs of each chick were exposed and observed for gross lessions. Also $0.1 \mathrm{~mL}$ of bile of each chick was collected to determine titre of the $E$. coli in bile of the chicks. To the $0.1 \mathrm{~mL}$ of bile, $0.9 \mathrm{~mL}$ of normal saline was added to get a 1:10 dilution. Then $0.1 \mathrm{ml}$ of the $1: 10$ bile dilution was transfered to $0.9 \mathrm{~mL}$ of normal saline so that a 1:100 dilution of each bile sample was made. Then $0.05 \mathrm{~mL}$ of each diluted bile was plated on Mcconkey agar and incubated at $37^{\circ} \mathrm{C}$ for 24 hours. Colonies of $E$. coli in the culture were identified by their cultural characteristics, cultural morphology, staining characteristics and microscopic morphology. The E. coli colonies $(\mathrm{X})$ were then counted under the microscope. $E$. coli colonies per $\mathrm{mL}$ of bile of each chick was calculated as titre of the bacterium in the bile by the formular:

Bacterial titre(Colony forming units per $\mathrm{mL}$ of bile) $=\frac{\mathrm{X}}{5} \times 10,000 \mathrm{CUF} / \mathrm{mL}$.

Means of the E. coli colony forming units in bile of the four groups of infected chicks, treated with sulphadimidine and with same sulphadimidine stabilized in the synthetic AMS and that of the control group were compared for statistical differences by Analysis of Variance.

\section{RESULTS}

Clinical signs seen in chicks infected with resistant $E$. coli included mild diarrhea and huddling together. There was no mortality even in the untreated group and no gross lesion was observed in the $E$. coli infected chicks.

Mean bacterial titre of the untreated chicks was 33,200 $\pm 5200 \mathrm{CFU} / \mathrm{mL}$, while mean bacterial titres for the treated groups were $119,200 \times \pm 55,800 \mathrm{CFU} / \mathrm{mL}$, $295,200 \pm 106,400 \mathrm{CFU} / \mathrm{mL}, 14,800 \times \pm 1700 \mathrm{CFU} / \mathrm{mL}$, and $5200 \pm 1400 \mathrm{CFU} / \mathrm{mL}$ for the groups treated with 1 g/litre (sulphadimidine), $1 \mathrm{~g}$ /litre (sulphadimidine in AMS), $0.75 \mathrm{~g} /$ litre (sulphadimidine) and $0.75 \mathrm{~g} /$ litre (sulphadimidine in AMS), respectively.

There was no significant difference $(\mathrm{P}>0.05)$ between $33,200 \pm 5200 \mathrm{CFU} / \mathrm{mL}$ of the control and 119,200 \pm $55,800 \mathrm{CFU} / \mathrm{mL}$ of the group treated at sulphadimidine rate of $1 \mathrm{~g} /$ litre and $14,800 \pm 1700 \mathrm{CFU} / \mathrm{mL}$ of the group treated at sulphadimidine rate of 0.75 g/litre. Bacterial titre, $5200 \pm 1400 \mathrm{CFU} / \mathrm{mL}$ of the group treated at sulphadimidine rate of $0.75 \mathrm{~g} /$ litre with the AMS-sulphadimidine drug, was significantly $(\mathrm{P}<0.05)$, less than the $33,200 \pm 5200 \mathrm{CFU} / \mathrm{mL}$ of the control group while $295,200 \pm 106,400 \mathrm{CFU} / \mathrm{mL}$ of the group treated at sulphadimidine rate of $1 \mathrm{~g} /$ litre with the AMS-sulphadimidine drug was significantly $(\mathrm{P}<0.05)$ higher than that 
of the control.

Bacterial titres of the sulphadimidine-resistant E. coli in bile of infected chicks, treated with sulphadimidine stabilized in Aluminium-Magnesium Silicate are as on Table 1.

\section{DISCUSSION}

That treatment with sulphadimidine had no significant effect on the bacterial titre in bile of treated chicks both at dose rate of $1 \mathrm{~g} /$ litre and at $0.75 \mathrm{~g} /$ litre confirms that the $E$. coli isolate used for the experimental infection was resistant to sulphadimidine.

Stabilizing sulphadimidine in Aluminium-Magnesium Silicate caused bacterial multiplication in chicks treated at dose rate of $1 \mathrm{~g} /$ litre but at dose rate of $0.75 \mathrm{~g} /$ litre, it produced significant reduction in the bacterial titre.

Drugs have both the desired effects and side effects. Sulphadimidine has been reported to cause immunosuppresion in young chicks at high doses [11]. It appears that at the higher dose, AMS potentiation of sulphadimidine made its side effect more prominent than whatever antibacterial effect it had on the resistant $E$. coli, while at the lower dose, it potentiated the antibacterial effect more than the side effect.

Immunosupression, as a side effect of sulphadimidine, occures at high doses of the drug (22). So, stabilizing sulphadimidine with the AMS may have increased the drug's effect so much that $1 \mathrm{~g}$ /litre became overdose thus increasing immune suppression.Since the $E$. coli was resistant to sulphadimidine, suppressing immune response of the chicks meant the infection was free, both from the chicks' immune responses and from antibacterial effects of the drug, hence the bacterial multiplication that occured.

Reduction of the bacterial titre from 33,200 CFU/mL to $14,800 \mathrm{CFU} / \mathrm{mL}$ when the resistant infection was treated with sulphadimidine alone at reduced dose rate of $0.75 \mathrm{~g} /$ litre suports the suggestion that the flareup noticed when the infection was treated with the AMS-stabilized sulphadimidine at the higher dose was due to side effect of the drug, because sulphadimidine-induced immune suppression occures only at high doses of the drug [23]. Nanoparticles enhance delivery of chemotherapeutics to desired targets [13]. So, a combination of prolonged bioavailability of sulphadimidine, enhanced delivery of the drug to targets by the AMS (nanoparticles) and reduction in immune supressive side effect of sulphadimidine by reducing the dose, may be responsible for the antibacterial effect of sulphadimidine against the E. coli isolate which was resistant to it

Bacterial titre of $5200 \pm 1400 \mathrm{CFU} / \mathrm{mL}$ recorded in the group of chicks treated with the AMS-sulphadimidine drug, at dose rate of $0.75 \mathrm{~g} /$ /itre was significantly less than the mean titre of the untreated group of chicks. This suggests that the AMS potentiated only antibacterial action of sulphadimidine at the lower dose rate. So, the drug became effective even against the isolate that was resistant to it.

Reduction of titre of the resistant E. coli from 33,200 \pm 5400 in the control, to $5200 \pm 1400 \mathrm{CFU} / \mathrm{mL}$ in the group treated with the AMS-stabilized sulphadimidine at dose rate of $0.75 \mathrm{~g} /$ litre is $84 \%$ bacterial clearance.

Treatment of Salmonella gallinarum-infected chicks with $10 \mathrm{mg} / \mathrm{kg}$ Ampicillin which is recomended dose of the drug achieved $81 \%$ bacterial clearance [20]. Ezeibe et al. [22] have also reported that when mice infected with Helignosomoides bakeri were treated with piperazine at the recomended dose of $110 \mathrm{mg} / \mathrm{kg}$, the helminth Eggs Per Gram (EPG) of faeces reduced by $83 \%$. If these recomended doses of drugs achieve these levels of reduction of infections and they are accepted as effective treatments, it means that the $84 \%$ reduction in infection of the resistant $E$. coli is also an effective treatment of the infection. So, AMS may have made sulphadimidine regain its antibacterial effect against the resistant $E$. coli infection.

In addition to the therapeutic effect achieved with this lower dose of sulphadimidine, it is also of economic sig-

Table 1. Titre of sulphadimidine-resistant Escherichia coli in bile of infected chicks treated with sulphadimidine stabilized with Aluminium-Magnesium Silicate.

\begin{tabular}{|c|c|c|c|c|c|}
\hline \multirow[t]{3}{*}{ Chick } & \multicolumn{5}{|c|}{ E. coli Colony Forming Units Per mL of Bile (CFU/mL) } \\
\hline & \multicolumn{2}{|c|}{$1 \mathrm{~g} /$ litre } & \multicolumn{2}{|c|}{$0.75 \mathrm{~g} /$ litre } & \multirow[t]{2}{*}{ Control } \\
\hline & Sulph & Sulph-AMS & Sulph & Sulph-AMS & \\
\hline 1 & 72,000 & 56,000 & 12,000 & 8000 & 40,000 \\
\hline 2 & 340,000 & 604,000 & 18,000 & 2000 & 42,000 \\
\hline 3 & 32,000 & 400,000 & 20,000 & 6000 & 12,000 \\
\hline 4 & 72,000 & 360,000 & 12,000 & 8000 & 36,000 \\
\hline 5 & 80,000 & 560,000 & 12,000 & 2000 & 36,000 \\
\hline Mean & $119,200 \pm 55,800^{\mathrm{ac}}$ & $295,200 \pm 106,00^{c}$ & $14,800 \pm 1740^{\mathrm{a}}$ & $5200 \pm 1400^{\mathrm{b}}$ & $33,200 \pm 5400^{\mathrm{a}}$ \\
\hline
\end{tabular}


nificance as reduction in amount of active drugs needed for teatments would lead to reduction in costs of treatments. There is also a public health benefit to be derived from use of lower doses of drugs to achieve effective treatment of infections in food animals because, it will lead to reduction in amount of drug recidues in tissues of treated animals. Reduction in amount of drug recidues in tissues of food animals will reduce incidence of development of drug resistance by pathogens in humanbeings who eat meat, eggs and milk of the animals.

\section{REFERENCES}

[1] NTP (1987) Abstract for Tr-318-Ampicillin Trihydrate (CASRN 7177-48-2) Toxicology and oarcinogenesis studies of Ampicillin Trihydrate (CAS No. 7177-48-2) in F344/N Rats and 36C 3F, Mice (Gavage studies). NTP Study Reports, National Toxicological Program, USA Government.

[2] Ewers, C., Anto, E.M., Diehi, I., Philip, H.C. and Wieler, L.H. (2004) Molecular epidemiology of Avian pathogenic Escherichia coli isolated from colisepticaemia in poultry. Veterinary Microbiology, 104, 91-101. doi:10.1016/j.vetmic.2004.09.008

[3] Johnson, J.R., Sannes, M.R., Croy, C., Johnson, B., Clabots, C., Kustowski, M.A., Bender, J., Smith, K.E., Winokur, P.L. and Belongia, E.A. (2007) Antimicrobial drug-resistant Esherichia coli from human and poultry products Minnesota and Wisconsin. Emerging Infectious Diseases, 13, 1576-1585. doi:10.3201/eid1306.061576

[4] Butaye, P. and Jasson, V. (2000) E. coli infections: CODACERVA publications. www.coda-cerva.com

[5] Murray, P.R. (2007) Mannual of clinical microbiology. 9th Edition, ASM Press, Washington.

[6] McMullin, P. (2004) Poultry disease. www.poultrysite.com

[7] Majowicz, S.E., Musto, J., Scallan, E., Angulo, F.J., Kir, K.M., O-Brien, S.J., Jones, T.F., Fazil, A. and Hoekkstra, R.M. (2010) The global burden of collibacillosis. Clinical Infectious Diseases, 50, 882-889. doi:10.1086/650733

[8] Shane, S.M. (2009) Reducing pathogenic E. coli infection by vaccination. World Poultry, 25, 21-23.

[9] Diarra, M.S., Silversides, F.G., Diarrasouba, F., Pritchard, J., Masson, L., Brouseau, R., Bonnet, C., Delaquis, P., Bach, S., Skura, B.J. and Topp, E. (2007) Impact of food supplementation with antimicrobial agents on growth performance of broiler chickens, Clostridium perfringes and enterococcus counts and antibiotic resistance phenotypes and distribution of antimicrobial resistance determinants in Escherichia coli isolates. Environmental Microbiology, 73, 6566-6576. doi:10.1128/AEM.01086-07
[10] Brunton, L.L. (2006) The pharmacological basis of therapeutics. McGraw Hill, New York.

[11] Craig, C.R. (1994) Mordern pharmacology with clinical applications. Lippincott Williams and Wilkins, New York.

[12] Vanderbilt, R.T. (1992) Veegum-The versatile ingredient for pharmaceutical formulations. RT Vanderbilt Company, Inc., New York. www.rtvanderbilt.com

[13] Cristina, E., Ivan, P. and Kevin, R. (2007) Nanomaterials and nanoparticles: Sources and toxicity. Biointerphases, 2, MR17-MR71. dol:10.1116/12815690.PMD.20419892

[14] Smith, D.G. (1984) The Cambridge Encyclopedia of earth science. Cambridge University Press, London.

[15] Wai, K., Dekay, H.G. and Banker, G.S. (1996) Application of Montmorillonite in tablet making. Journal of Pharmaceutical Sciences, 55, 1244-1248. doi:10.1002/jps.2600551116

[16] Crowther, J. (1995) Advance learners dictionary. Oxford University Press, New York.

[17] Mineral Gallaries (2012) Zeolite Group www.galleries.com/zeolite.htm

[18] Brent, W., Gunderson, G.H., Ross, K.H.I. and John, C.R. (2001) What do we really know about antibiotics pharmacodynamics? Pharmacotherapy, 21, 28-31.

[19] Ezeibe, M.C.O., Elendu-Eleke, N.P., Okoroafor, O.N. and Ngene, A.A. (2012) Adjuvant effect of a synthetic Aluminium-Magnesium Silicate on chloroquine phosphate, against Plasmodium berghei. Nature Precedings. http:hdt:10101/npre 201226749./posted 2 Jan 2012

[20] Ezeibe, M.C.O., Anosa, G.N., Okorie, O.K., Elendu-Eleke, N.P., Okoroafor, O.N., Ngene, A.A. and Chikelu, O.N. (2012) Aluminium-Magnesium Silicate enhances antibacterial activity of Ampicillin trihydrate, against $S$. gallinarum. Nature Preceding. http:hdt.handle.net/10101/npre.2012.6814.1.posted23Jan. $\underline{2012}$

[21] Ezeibe, M.C.O., Okafor, U.C., Okoroafor, O.N., Eze, J.I., Ngene, A.A., Animoke, P.C. and Mbuko, I.J. (2011) Effect of Aluminium-Magnesium Silicate on anticcocidial activity of sulphadimidine. Tropical Vet, 29, 41-44.

[22] Ezeibe, M.C.O., Dire, C.D., Anosa, G.N., Chikelu, O.N., Okoroafor, O.N., Okorie, O.K., Ngene, A.A., Idika, I.K., Ogunniran, T.M. and Ezeala, I.E. (2012) Efficacy of piperzine citrate, stabilized with Aluminium-Magnesium Silicate, against Helignosomoides bakeri. Health, 4, 890892.

[23] El-Mahmoudy, A., Mahmoud, M.E., Fararh, K., ElMagdoub, A. and Awidat, S. (2012) Sulphadimidine suppresses major histocompatibility complex expression in broiler chickens. British Journal of Pharmacology and Toxicology, 3, 2044-2046. 